\title{
Characteristics and Constraint Evidences of the Pegmatite Veins in Lubishi Mining Sector, Kalehe District, Eastern DR Congo
}

\author{
Mupenge Mutiyamuogo Parfait ${ }^{1 *}$, Raha Mulumba ${ }^{2}$, Abdourahamane Barry Diogo ${ }^{1}$, Paul Ndizine Burhama $^{3}$ \\ ${ }^{1}$ Department of Geosciences, Pan African University of Life and Earth Sciences, University of Ibadan, P.O Box 200284 Ibadan, \\ Nigeria \\ ${ }^{2}$ College of Mining and Geology, Université Libre des Grands Lacs, ULGL, Bukavu, Congo \\ ${ }^{3}$ Department of Geology, Université de Bukavu, P.O Box 162 Bukavu, Congo
}

Corresponding Author Email: parfaitmupenge@gmail.com

https://doi.org/10.18280/eesrj.080301

Received: 14 April 2021

Accepted: 24 June 2021

\section{Keywords:}

Lubishi pegmatites, characteristic, structural imprints, constraint stress

\begin{abstract}
The Lubishi pegmatites of South Kivu Province (DR Congo) in the Kibaran belt, which were studied to elucidate the structural imprints and characteristics of pegmatitic rocks associated with $\mathrm{Sn}$ - $\mathrm{Nb}$ - Ta mineralization, revealed that the pegmatite veins have a general orientation trend of $\mathrm{N} 150^{\circ} \mathrm{E}$, similar to the Numbi mining sector, and are perpendicular to the Kibara metasediments. The pegmatite, which is composed of quartz, muscovite, and feldspar, was altered as a result of surface weathering. Due to the ambient climatic condition, the main mineralogy of the various pegmatite zones has been subjected to severe alteration with the change of feldspar to kaolinite. Micro and macro veins of pegmatite were discovered during the structural examination. The constraint stresses $1=\mathrm{N} 358^{\circ} \mathrm{E} / 20^{\circ} \mathrm{NNW}, 2=\mathrm{N} 200^{\circ} \mathrm{E} / 70^{\circ} \mathrm{SSW}$, and $3=\mathrm{N} 88^{\circ} \mathrm{E} / 20^{\circ} \mathrm{ENE}$ produced micro and macro veins of pegmatite, according to the structural research. The Lubishi pegmatite's overall orientation trend can be exploited for future geological exploration. To complete this study, a geochemical examination should be conducted to identify the makeup of these pegmatite.
\end{abstract}

\section{INTRODUCTION}

Pegmatites are intrusive igneous rocks that are distinguished by the size of individual crystals and the immediate crystallization of several mineral phases. They generate a wider diversity of gemstones than any other rock type, and they've also produced some of the world's biggest jewels.

The water-rich part of a granite-like molt forms the big crystals. As the molten rock begins to solidify, the elements that it contains begin to crystallize [1]. The largest gemstones and some quite rare gemstone varieties are found in gem pockets at the centre of the pegmatite, where they have formed from the hot concentrated mineral-rich fluid that was the last to crystallize. Pegmatites are texturally complex igneous rocks marked by some combination of extremely large but variable crystal size, spatial zonation of minerals, prominent anisotropy of crystal orientations from the margins inward, and skeletal, radial, or graphic intergrowth habits of crystals [2]. Generally, pegmatites hold various metallic and nonmetallic minerals that are of enormous economic benefit. The Pegmatite is an important source of tantalum (Ta), niobium $(\mathrm{Nb})$ and tin $(\mathrm{Sn})$ used in many industrial applications. The metals of the tin group ( $\mathrm{Sn}, \mathrm{Nb}, \mathrm{Ta}, \mathrm{Be}, \mathrm{Li}, \mathrm{W}$ ) are found in the Mesoproterozoic Kibarian. Granitoids from the Kibara belt consist of granites as well as pegmatites and they chronologically tie up to the Mesoproterozoic formations (1600-900Ma) situated in the Maniema, Kivu and Katanga provinces in Democratic Republic of Congo [3]. This belt forms large province of metallogeny containing abundant granite related ore deposits, which are rich in minerals like cassiterite (SnO2), spodumene (LiAlSi2O6), columbitetantalite ( $\mathrm{Nb}$, Ta)2O5), beryl (Be3Al2Si6O18), wolframite ((Fe, Mn) WO4), amblygonite (Li, Na) (AlFPO4), monazite (Ce, $\mathrm{La}, \mathrm{Y}, \mathrm{Nd}, \mathrm{Th})$ and $\mathrm{Sn}-\mathrm{Nb}-\mathrm{Ta}$ in pegmatite $[4,5,7]$. The deposits and indices of the tin group [tin, wolframite, Coltan (Colombite- Tantalite), beryl, rare earth] are located in the eastern part of the Congo (Kivu) where they form a belt extending over $700 \mathrm{~km}$, from Ituri in the north to the NorthWest end of the southern Copper belt. Niobium-tantalum and part of the tin are present in pegmatites that have a spatial relation with these S-type granites [6]. The proposed study area is one of the few areas identified to have Tin-NiobiumTantalum mineralization. However, there is a lack of detailed information about the structural control of mineralization, the processes that lead to its formation, and the economic viability of Tin-Niobium-Tantalum mineralization in the proposed study area. This study was prompted by a lack of data on geological mapping, structural studies, and potential mineralization zones. This research is aimed at using integrated approaches (geological mapping, petrography, and structural geology) to determine the Characteristics and constraint evidences of the pegmatite veins will be useful for economical adventures of geological explorations.

\section{LOCATION OF THE STUDY AREA}

The research area is located in the Lubishi mining sector field, Kalehe district, Eastern Democratic Republic of Congo, 
70 kilometers west of Bukavu city, and is defined by the geographic coordinates Lat.01.78 - 1.82 and Long.27.7928.88 (Figure 2).

The study area is underlain in part by the Kibaran Orogenic Belt lithologies. The Kibara orogen formed and evolved between two pre- Mesoproterozoic domains: the ArchaeanPalaeoproterozoic Congo craton to the west and the north, and the Archaean- and Palaeoproterozoic Tanzania craton and Bangweulu Block to the east and the south. The Kibaran belt covers several center-east African countries (Democratic Republic of Congo, Rwanda, Burundi, Uganda) and contains about 100 year extensive record of $\mathrm{Sn}$ and Ta assembly; additional Ta-Nb-Sn provinces are established in South Africa, Zimbabwe, Nigeria, Namibia, Madagascar, Mozambique, Somalia, Ethiopia and Egypt [7, 8], Figure 1. The Kibarian chain is full of stanniferous and auriferous deposits located in the eastern part of the DRC. Stanniferous mineralization is related to G4 granites and is contained in pegmatites and / or quartz veins $[9,10]$. Gold mineralization is associated with quartz veins formed at high temperatures and pressures different from tin and tungsten veins. Sn-Nb-Ta ore mineralisation in the Kibara belt, takes place chiefly in pegmatites and quartz veins that traverse the Kibara metasediments $[11,12]$. Besides, the $\mathrm{Sn}-\mathrm{Nb}-\mathrm{Ta}$ ore minerals are transported by erosion through rivers, rain water currents, streams and are deposited as eluvium and alluvium or stream sediments along meanders [7]. Subsequently, these ores are secondary ore deposits and can be mined same as primary ores [13]. The tectonic episode is associated with the Syncollisional peraluminous granite (S-type) and post orogenic fractionation-derived pegmatite [14]. The general orientation of the Kibarian is NE-SW in the Great Lakes region, with frequent transfers to the NW, notably to West Lake Kivu and Maniema Kibarian terrain $[15,16]$.

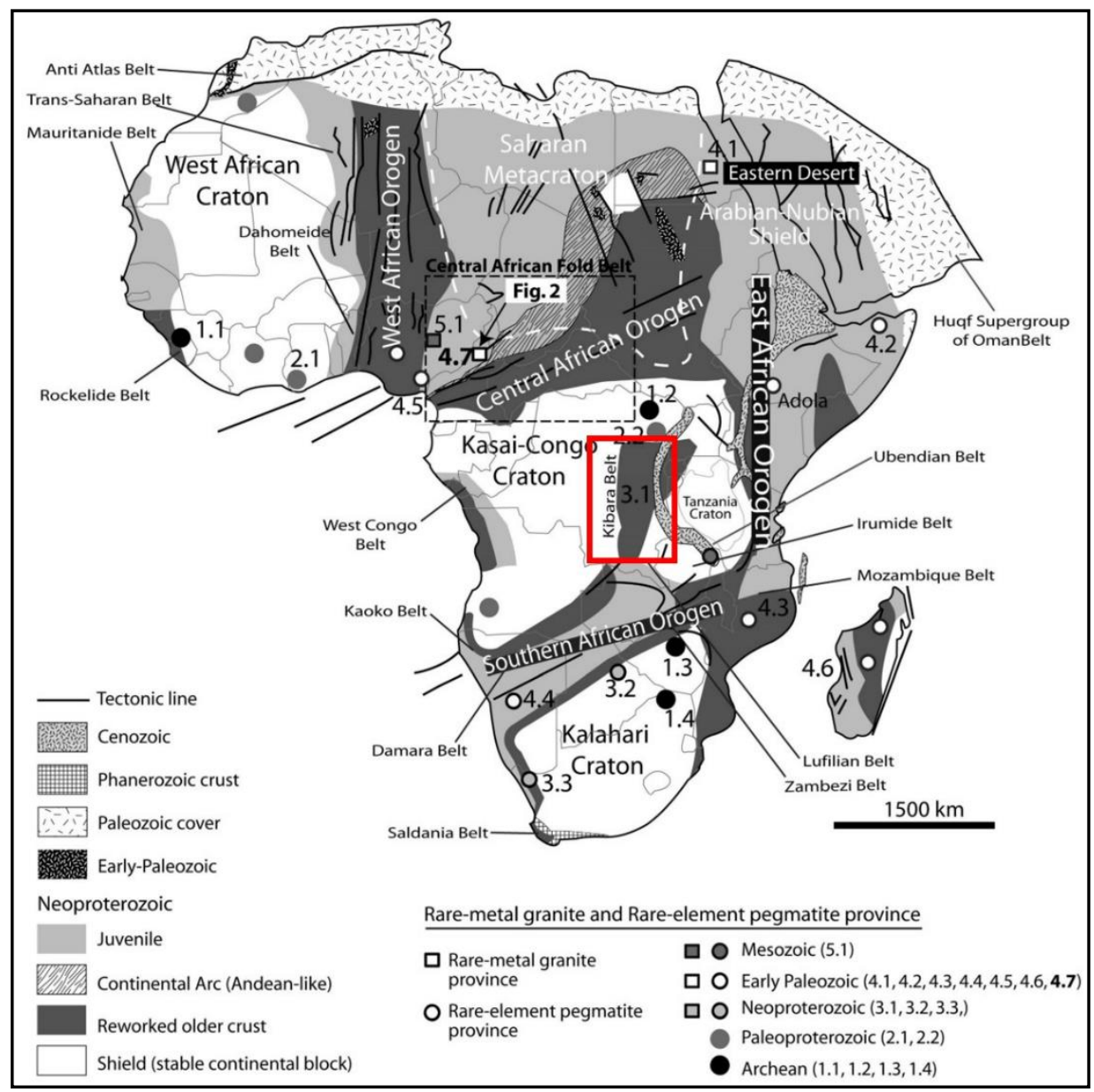

Figure 1. The study area is located inside the Pan African belt network, as well as the African rare-metal granite and rare-element pegmatite province

\section{LOCAL GEOLOGY}

The Kivu region is essentially constituted by the ancient formations belonging to the Burundian.

A vast expanse is occupied by an immense massif of granite. We observe points and small massifs of basic rocks (gabbros or diorites) towards the East. The grounds are covered with a thick mantle of metamorphic basalts. To the east, the folded Burundian beds are more or less metamorphic, while towards the west, the folds fade and the layers are almost horizontal and not metamorphic [17]. Generally, the local geology consists of three structural assemblages consisting of a Precambrian basement, a volcanic cover to the south and north of Lake Kivu and finally limestone lacustrine deposits that line the bottom of the main valleys at the edge of the lake [18]. The Kalehe formations are anterior Precambrian and associated with the Itombwe supergroup in East Kivu. Rocks outcropping along Lake Kivu between Katana and Kalehe consist mainly of graphitic black shales, banded red shales, quartzites, ferruginous lamina sandstone, and conglomeratic sandstones with generally weak metamorphism and directed $\mathrm{N}$ to $\mathrm{NE}$ structural directions; corresponding to two superposed 
tectonics, the latter giving N-S folds. They are unconformably overlain by the characteristic mixture of the Tshibangu group [19] and intruded by the Nyamukubi granites (whose probable age of intrusion is the same as the other "tin granites" of the region, i.e. $976 \pm 10 \mathrm{ma}$, but whose isotopic equilibrium has been disturbed by more recent events. The Bitale group (lower Kibarien) in which the kalehe includes all previously considered Ruzizian (2000-1800 Ma) or Archaean terrains, and Bitale formations, Bugarama, quartzites and the Kamanyola-Uvira migmatites, the lower Masisi-Sake series, the Luhule-Mobisio formations, and the Kasika-Luntukulu formations [20]. Lubishi is located in the Alkaline complex where we have abundance of mesoproterozoic rocks, composed of two mica granite postdated by leucogranite related to the $\mathrm{Sn}-\mathrm{Ta}-\mathrm{Nb}$ mineralisation and Itombwe group formations [21], Figure 2.

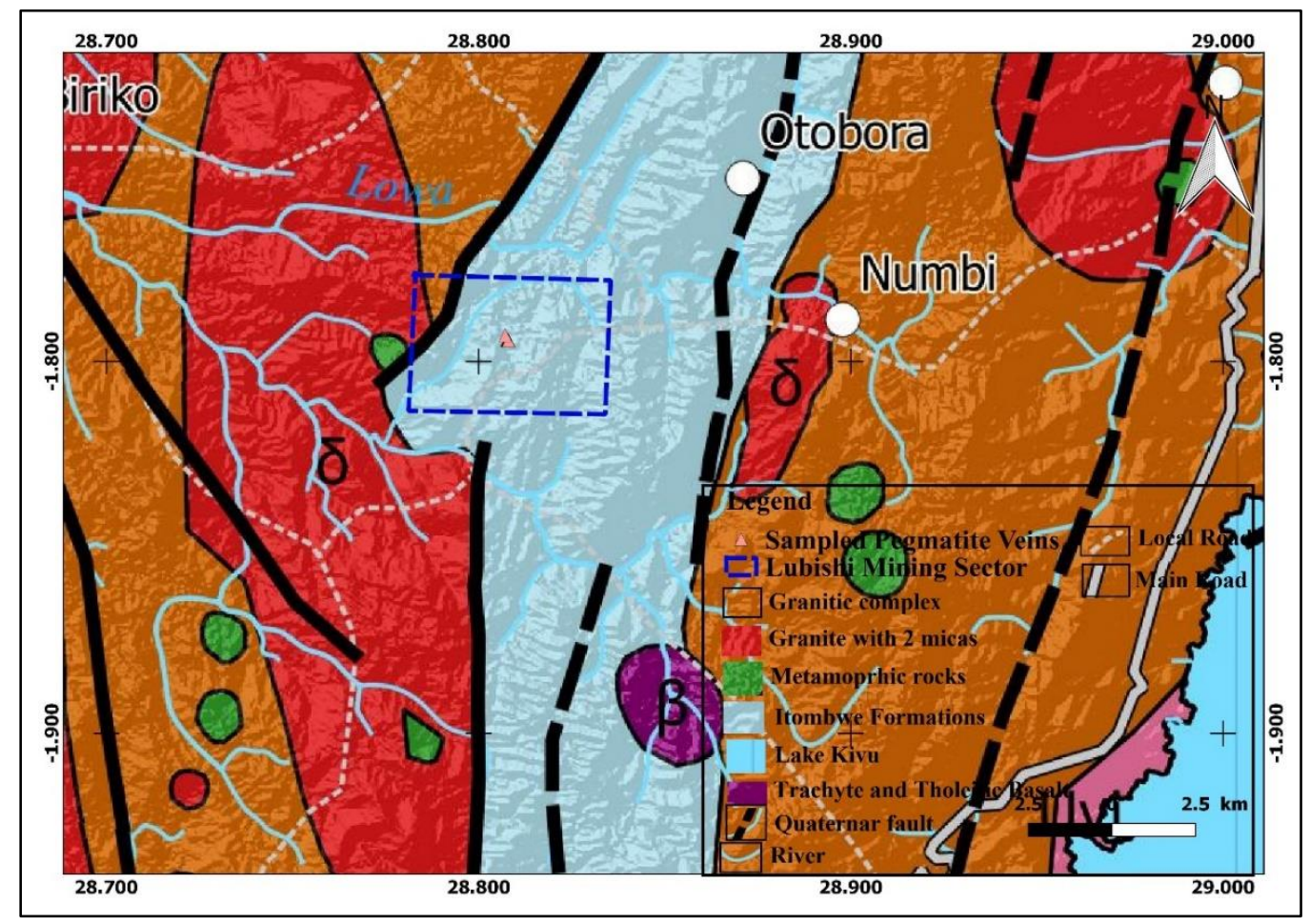

Figure 2. Local geological map of the study area

\section{METHODOLOGY}

The field work exercise was accomplished with the use of several field materials such as topographic map, Global Positioning System (GPS), compass clinometer, geological hammer, field notebook, pen, crayon, tape rule, cutlass, and tracing paper. The observation made consisted to describe the macroscopic characteristics of pegmatite with regard to the environmental evolution of veins. In situ measurements of strikes and dips of the principal pegmatite veins were taken for structural study with compass clinometers (Figure $3 \mathrm{a}$ and $\mathrm{b}$ ). This will later help to deduce the direction of the tectonic forces that produce some structural elements observed, the general orientation trend of the pegmatite veins has been compared to the orientation of all the fractures within the study are, the lasted generated automatically with PCI geomatica and Rockworks software respectively. Observations made include pegmatite and quartz veins. Carefully selected whole rock samples were crushed at the Thin-section laboratory of Department of Geology, University of Burundi, Burundi. Measured structural parameters were integrally statistically processed using Dips Software. Stereonets have been made and the constraint axes including: $\sigma 1, \sigma 2$ and $\sigma 3$ have been established in order to determine the deformation axes that generated pegmatites veins in the study area.

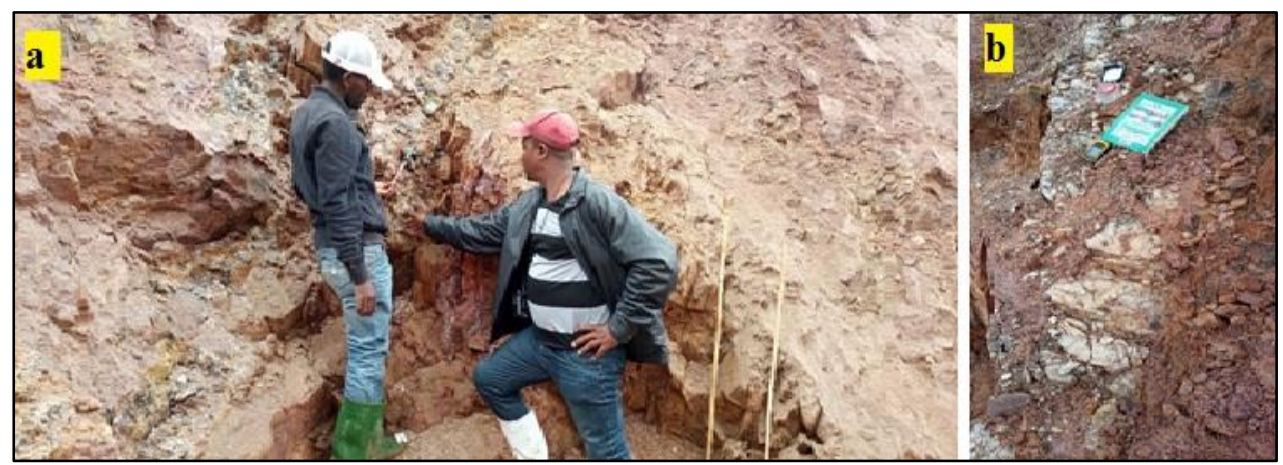

Figure 3. The field investigation (a) and some used materials (b) 


\section{RESULTS}

\subsection{Characteristic of the pegmatite}

The pegmatite is a very coarse grain rock with big crystal of feldspar and quartz with some micas (Figure 7c). It is a lightcolored rock due of the prevalence of felsic elements and it is hosted by banded gneiss. During the final stages of crystallization, it crystallizes from residual melt. Pegmatite appears as filons (in veins) in the Lubishi mining area (Figure $7 b, c$ and d).

This pegmatite is mineralized because it contains economic minerals. Macroscopic field observations on the pegmatites demonstrate that their compositions are similar to simple granitic compositions of micas, quartz, and feldspars, with micas being the most abundant (Figure 4a). The composition close to simple granitic composition meaning that the magma has been refined through fractional crystallization to the lowest-temperature liquid that is possible for the final environment of its crystallization [2]. Individual pegmatite veins have been impacted by significant post-emplacement fracturing, resulting in complicated block displacements. The pegmatite was altered as a result of surface weathering. The basic mineralogy of the several pegmatite zones has undergone significant change. Water precipitation has a major part in pegmatite alteration since this zone is located in a tropical environment with abundant precipitation. In these mining sector, Pegmatite found in veins is highly altered wherever it is found in the study area, they are found in altered schist (Figure 5b) or intruded barren granite (Figure 5c). The feldspars turn into kaolinite and sericite. Due to the climate, feldspar undergoes a high degree of alteration, resulting in the formation of whitish Kaolinite (Figure 4b), while other iron oxides in yellow and red undergo alteration, resulting in the formation of Limonite and goethite.

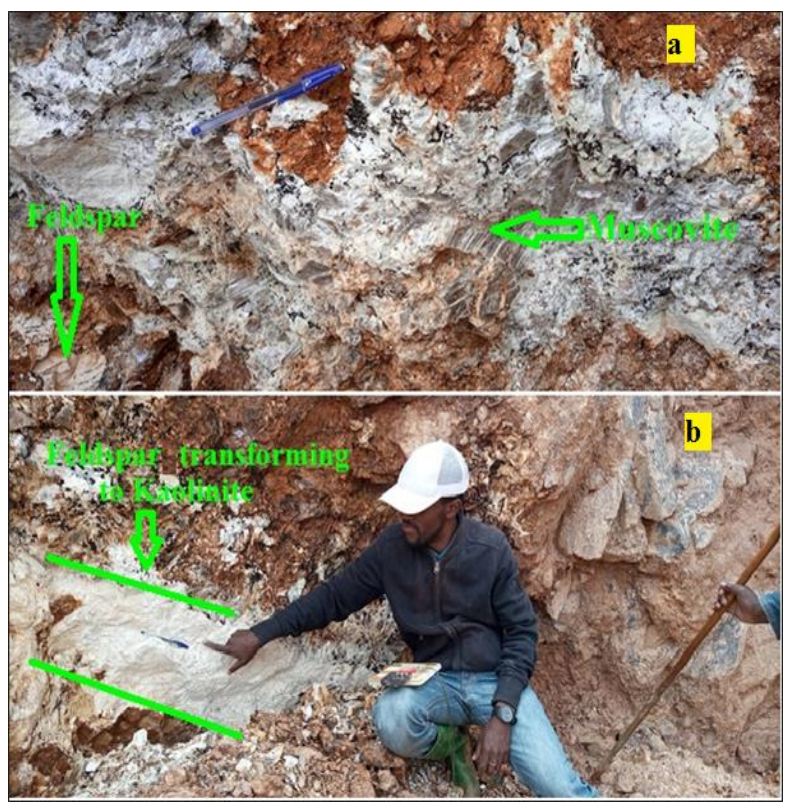

Figure 4. The abundance of Micas in the pegmatite (a) and transformation of feldspar in kaolinite (b). Micas in the pegmatite (a) and transformation of feldspar in kaolinite (b)

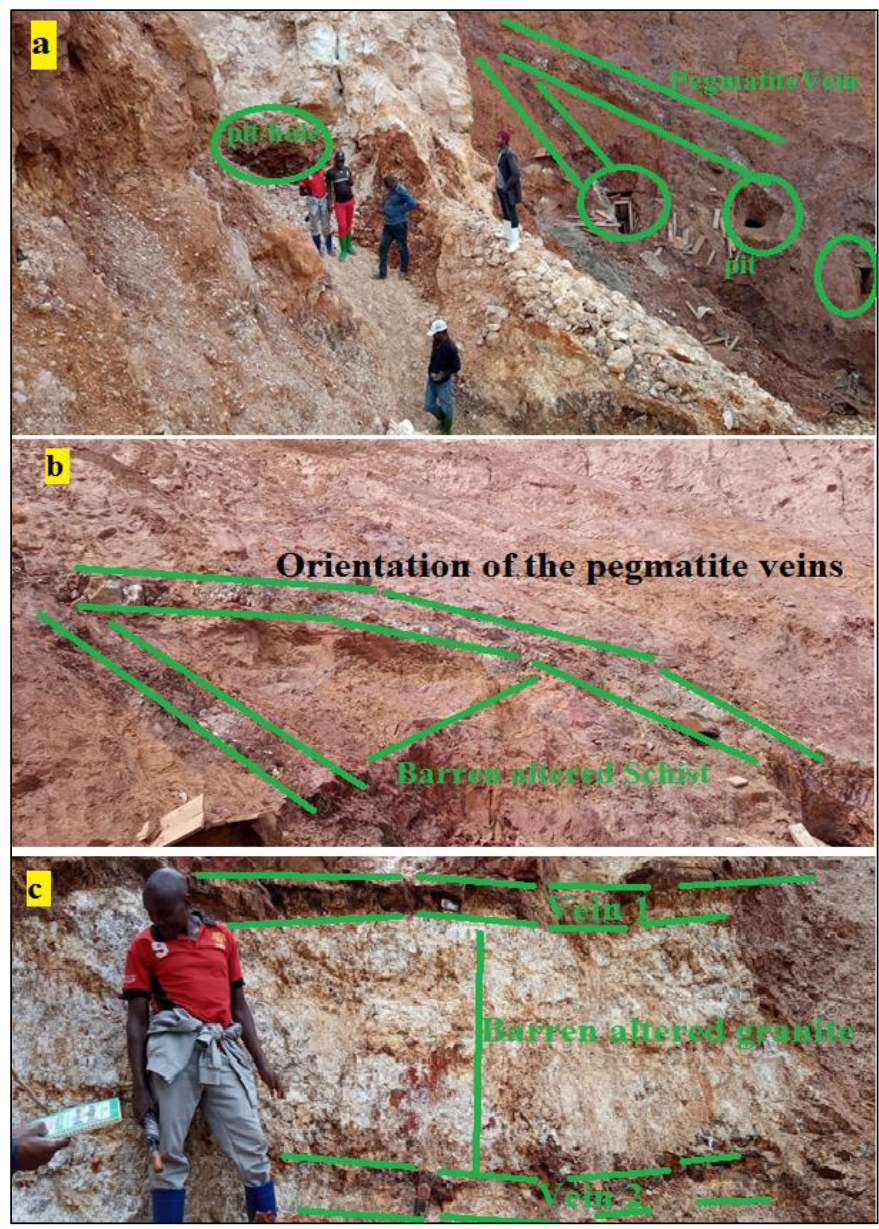

Figure 5. The pegmatite veins orientation (a), veins intruded barren altered schist (b), and barren altered granite with parallel pegmatite veins (c) 


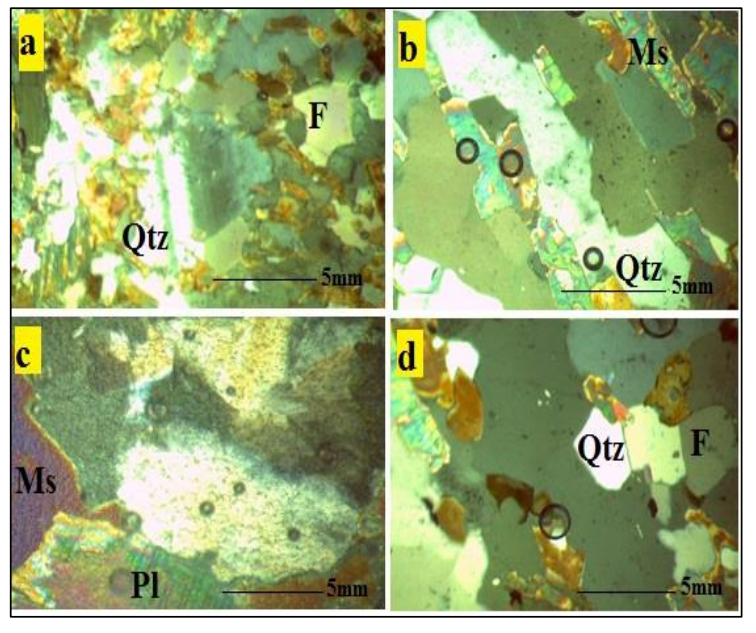

Figure 6. Photomicrograph of pegmatite selected samples (04) in trans-mitted light showing Quartz (Qtz), Feldspar(F), Plagioclase ( $\mathrm{Pl}$ ) and Muscovite (Ms)

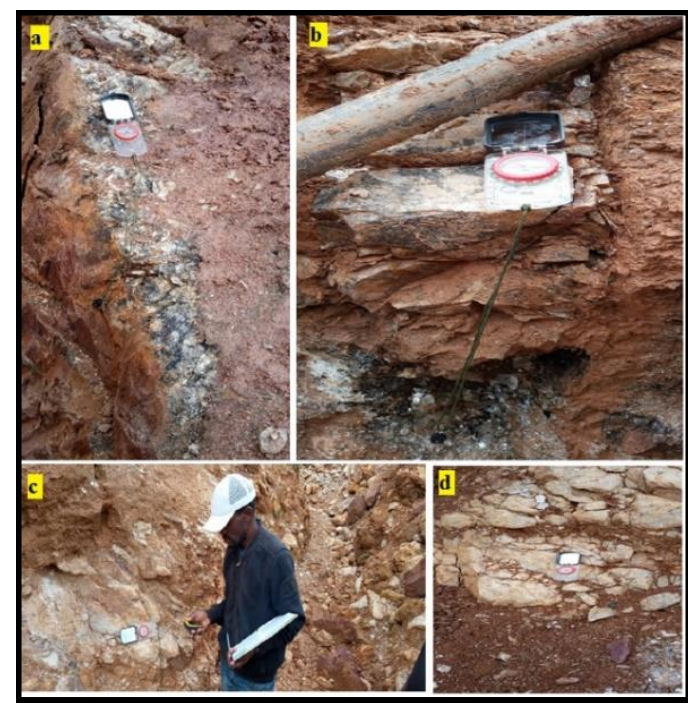

Figure 7. Showing pegmatite veins ( $a$ and $b$ ) and pegmatite as in pocket form (c and d)

The mineralogical assemblage of the deposits from weathering pegmatite desirable for ceramic purposes, since quartz will give the ceramic the needed strength and kaolinite will give the necessary plasticity to form the green body (unfired ceramic body) of the ceramic. The pegmatite seems to be mineralized with $\mathrm{Sn}-\mathrm{Ta}-\mathrm{Nb}$ mineralization that the presence of artisanal activities within the sector (Figure 5a). Mineralization of columbite-tantalite and cassiterite has been found in the Lubishi pegmatite's unmodified border and intermediate zone, where they appear as dispersed minerals. Micas are abundant in these pegmatites found in this mining sector, muscovite Micas in elongated plaquettes (Figure 6c) with a small quantity of Quartz, plagioclase, and feldspars (Figure 6 a,b,c and d).

Pegmatites are intrusions in granitic host rocks that manifest as large and tabular masses in a pocket form in the Lubishi region (Figure $7 \mathrm{c}$ and $\mathrm{d}$ ). They are a coarse-grained (varying from $1.7 \mathrm{~cm}$ to $15 \mathrm{~cm}$ ) creamy white rock with a distinctive look. Quartz, muscovite, biotite, and dull-dark flecks of tourmaline are the predominant mineral assemblages (with striations on the sides).

\section{CONSTRAINT EVIDENCES}

Fractures are structures that are formed under brittle condition. They occur when the rock is subjected to stress that is beyond its bearing capacity. It breaks up. Later the facture will be filled (mineralized). The structural measurements (Strike and dip) have been used, plotted, analyzed and processed in Dips Software to determine vein families and constraint axe trends.

The measurements of pegmatite veins are listed in Table 1. The veins show many families, according to their thickness we can differentiate two families of veins: micro veins $(10-30 \mathrm{~cm})$ and macro veins $(>30 \mathrm{~cm})$ (Table 1$)$. The high degree of felspar alteration in fractured rocks in the research region leads to the production of white kaolinite. The two sorts (groups) of veins are represented by these two clouds. The intersection of these two big circles helps us to establish the primary stresses that caused the zone's deformation. The normal component intermediate 2 is represented by the intersection of these big circles. $\mathrm{N} 200^{\circ} \mathrm{E} / 70^{\circ} \mathrm{SSW}$ are the strike and dip of 2 [22]; Figure 8c.

Figure 6 Photomicrograph of pegmatite selected samples (04) in transmitted light showing Quartz (Qtz), Feldspar(F), Plagioclase (Pl) and Muscovite (Ms). The stereogram indicates that the big circle of which $\sigma 2$ is the pole, bears the greatest normal principal stress $\sigma 1$ (sigmal on the diagram), the minimum normal principal stress $\sigma 3$ (sigma3 on the diagram), the primary tangential stress לmax (Tmax on the canvas) and sliding directions D1 and D2.

Table 1. Structural measurements of the Lubishi pegmatite veins

\begin{tabular}{cccccc}
\hline Longitude & Latitude & Elevation & Strike & Dip & Tickness \\
\hline $\mathbf{- 1 . 7 9 4 0 6 6}$ & 28.80769 & 2358.34 & $\mathrm{~N} 138^{\circ} \mathrm{E}$ & $70^{\circ} \mathrm{NW}$ & $25 \mathrm{~cm}$ \\
\hline $\mathbf{- 1 . 7 9 4 0 7 1}$ & 28.80768 & 2358.18 & $\mathrm{~N} 180^{\circ} \mathrm{E}$ & $58^{\circ} \mathrm{NW}$ & $20 \mathrm{~cm}$ \\
\hline $\mathbf{- 1 . 7 9 4 1 6 6}$ & 28.8077 & 2356.09 & $\mathrm{~N} 40^{\circ} \mathrm{E}$ & $85^{\circ} \mathrm{NE}$ & \\
\hline $\mathbf{- 1 . 7 9 4 2 0 2}$ & 28.80774 & 2354.95 & $\mathrm{~N} 40^{\circ} \mathrm{E}$ & $42^{\circ} \mathrm{NW}$ & $30 \mathrm{~cm}$ \\
\hline $\mathbf{- 1 . 7 9 4 2 0 5}$ & 28.80777 & 2352.75 & $\mathrm{~N} 40^{\circ} \mathrm{E}$ & $82^{\circ} \mathrm{NE}$ & \\
\hline $\mathbf{- 1 . 7 9 4 0 7 2}$ & 28.80773 & 2362.85 & $\mathrm{~N} 20^{\circ} \mathrm{E}$ & $78^{\circ} \mathrm{SW}$ & \\
\hline $\mathbf{- 1 . 7 9 4 1 4 8}$ & 28.80791 & 2367.81 & $\mathrm{~N} 150^{\circ} \mathrm{E}$ & $60^{\circ} \mathrm{NE}$ & $30 \mathrm{~cm}$ \\
\hline $\mathbf{- 1 . 7 9 4 0 7 8}$ & 28.80791 & 2364.77 & $\mathrm{~N} 158^{\circ} \mathrm{E}$ & $78^{\circ} \mathrm{SE}$ & $18 \mathrm{~cm}$ \\
\hline $\mathbf{- 1 . 7 9 4 2 6 7}$ & 28.80795 & 2367.02 & $\mathrm{~N} 40^{\circ} \mathrm{E}$ & $82^{\circ} \mathrm{NW}$ & $35 \mathrm{~cm}$ \\
\hline $\mathbf{- 1 . 7 9 4 3 5 8}$ & 28.80803 & 2369.51 & $\mathrm{~N} 170^{\circ} \mathrm{E}$ & $80^{\circ} \mathrm{NW}$ & $25 \mathrm{~cm}$ \\
\hline $\mathbf{- 1 . 7 9 4 4 1}$ & 28.80802 & 2370.90 & $\mathrm{~N} 145^{\circ} \mathrm{E}$ & $70^{\circ} \mathrm{NW}$ & \\
\hline $\mathbf{- 1 . 7 9 4 4 1 1}$ & 28.80801 & 2371.75 & $\mathrm{~N} 150^{\circ} \mathrm{E}$ & $80^{\circ} \mathrm{SW}$ & $15 \mathrm{~cm}$ \\
\hline $\mathbf{- 1 . 7 9 4 4 1 1}$ & 28.80801 & 2371.75 & $\mathrm{~N} 150^{\circ} \mathrm{E}$ & $80^{\circ} \mathrm{SW}$ & $15 \mathrm{~cm}$ \\
\hline $\mathbf{- 1 . 7 9 2 8 8 8}$ & 28.80712 & 2310.76 & $\mathrm{~N} 45^{\circ} \mathrm{E}$ & $42^{\circ} \mathrm{NW}$ & $30 \mathrm{~cm}$ \\
\hline
\end{tabular}




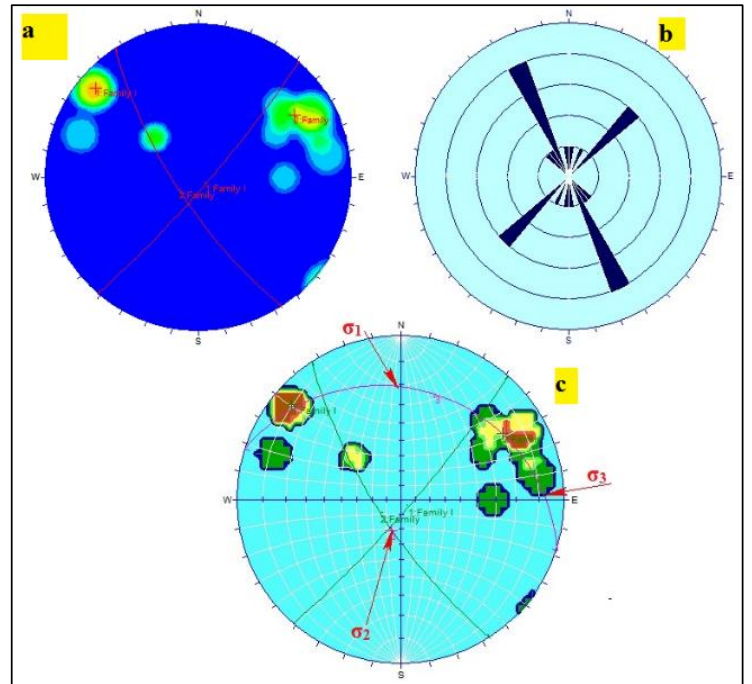

Figure 8. Stereonets showing a) pegmatite families and b) pegmatite preferential trend and c) stress generated the pegmatite veins

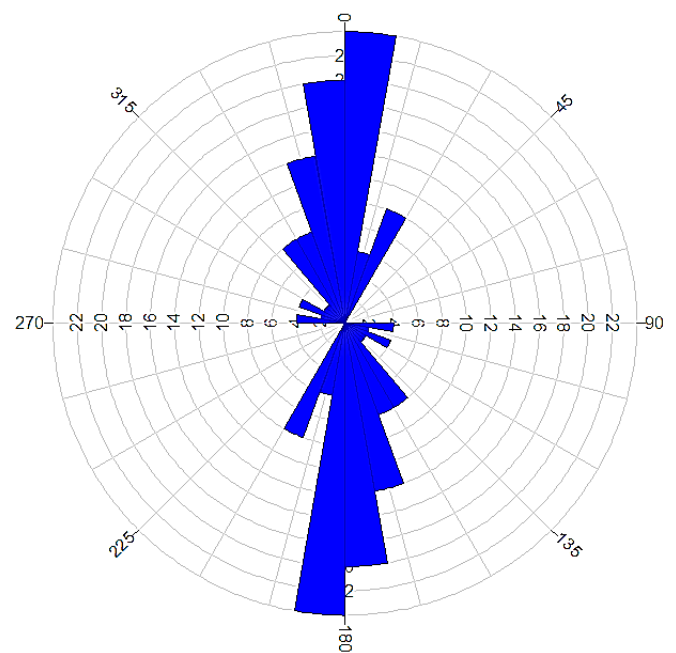

Rose Diagram

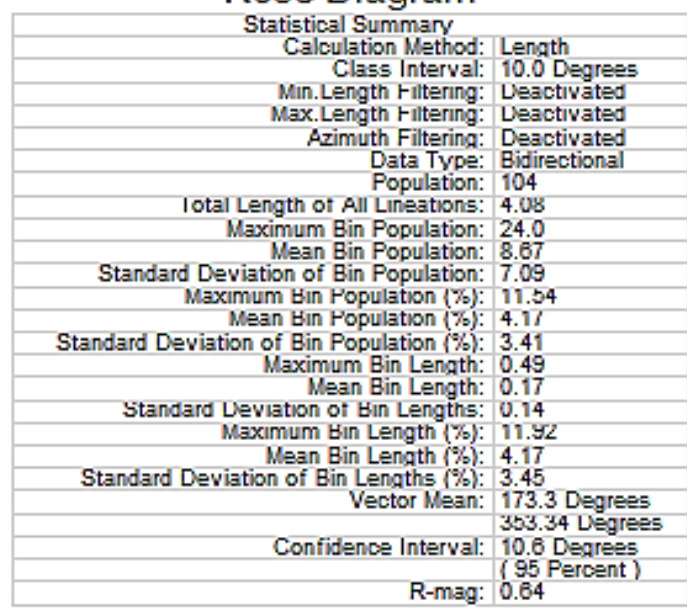

Figure 9. The Lubishi pegmatites veins' automatic orientation trend is depicted in a rose diagram

The sliding plane is represented by this large circle, D1 and D2 are the points on the slip plane where two huge circles representing the main families cross; their directions and dip are $\mathrm{N} 322^{\circ} \mathrm{E} / 13^{\circ} \mathrm{NWE}$ and $\mathrm{N} 43^{\circ} \mathrm{E} / 20^{\circ} \mathrm{NE}$, respectively. The sigma1(1) direction, sinking $\mathrm{N} 358^{\circ} \mathrm{E} / 20^{\circ} \mathrm{NNW}$ in the center of D1D2, can be found Sigma3 direction and dipping are found at $90^{\circ}$ of sigma1, we can get Sigma3 direction and dipping $\mathrm{N} 88^{\circ} \mathrm{E} / 20^{\circ} \mathrm{ENE}$, and Tmax direction and dipping $\mathrm{N} 37^{\circ} \mathrm{E} / 21^{\circ} \mathrm{NE}$ in the center of $\sigma 1 \sigma 3$. Tectonic processes have a significant impact on rock formations in the studied region, as evidenced by the presence of pegmatite-quartz veins in granites and other lithologies within Lubishi, indicating a compressive regime system linked subduction or collision [2325].

Briefly the general orientation of the pegmatite $\mathrm{N} 150^{\circ} \mathrm{E}$; NNW-SSE (Figure 8a) and comparatively to the general orientation trend of the fractures in the Lubishi area and its closed areas generated automatically which shows N-S (Figure 9 ), veins show the same general trend with the orientation fractures from Numbi mining sector $\left(\mathrm{N} 150^{\circ} \mathrm{E}\right.$ to $\left.\mathrm{N} 160^{\circ} \mathrm{E}\right)$ [26]; compared to the general orientation trend shown by the pegmatite in Manono- Kahungwe sector which trend $\mathrm{N} 40^{\circ} \mathrm{E}-$ $\mathrm{N} 50^{\circ} \mathrm{E}$ [23] and seems to be perpendicular to the Numbi and Lubishi mining sectors. This has to confirm that Numbi and Lubishi sectors show the same orientation trend for pegmatite veins perpendicular to the Kibara metasediments. Numbi and Lubishi can be mined pursuing the same orientation trend.

\section{CONCLUSION}

Studies on the Lubishi pegmatites of South Kivu Province (D.R.C.) in the Kibaran belt, which intruded the Mesoproterozoic Formation (1.6-0.9 Ga), revealed that pegmatite veins are found intruded in the granite formation within the study area, and these pegmatites are found altered (weathered) due to the climate condition, and the transformation of feldspar part to kaolinite should be mentioned. This kaolinite can be used for ceramic application. The petrographic studies revealed the occurrence of quartz, muscovite and small amount of feldspar. The structural investigations on the pegmatite veins have shown two main families of veins that have been used to get the stress generation of the veins within the zone. The Lubishi pegmatite veins show the same general orientation trend with the Numbi mining sector and this orientation is perpendicular to the Kibara metasediments. These characteristics may be used to guide exploration procedure in the Lubishi mining sector as well as the general orientation of pegmatite veins has been found with accuracy.

\section{REFERENCES}

[1] Oldershaw, C. (2005). in Encyclopedia of Geology. www.elsevier.com/encyclopedia-of-geology/elias/97808-102908-4.

[2] David London. "Pegmatites", Elsevier BV, 2021. WWW.sciencedirect.com/topics/earth-and-planetarysciences/pegmatite.

[3] Tack, L., Wingate, M.T.D., De Waele, B., Meert, J., Belousova, E., Griffin, B., Tahon, A.,Fernandez-Alonso, M. (2010). The 1375 Ma"Kibaran event" in Central Africa: Prominent emplacement of bimodal magmatism under extensional regime. Precambrian Res., 180(1-2): 1-22. https://doi.org/10.1016/j.precamres.2010.02.022

[4] Dewaele, S., Henjes-Kunst, F.,Melcher, F., Sitnikova, M., Burgess, R., Gerdes, A., Fernandez-Alonso, M., De Clerq, F., Muchez, P., Lehmann, B. (2011). Late 
Neoproterozoic overprinting of the cassiterite and columbite-tantalite bearing pegmatites of the Gatumba area, Rwanda (Central Africa). J. Afr. Earth Sci., 61(1): 10-26. https://doi.org/10.1016/j.jafrearsci.2011.04.004

[5] Dill, H.G. (2015). Pegmatites and aplites: Their genetic and applied ore geology. Ore Geol. Rev., 69: 417-561. https://doi.org/10.1016/j.oregeorev.2015.02.022

[6] Varlamoff, N. (1972). Central and West African raremetal granitic pegmatites, related aplites, quartz veins and mineral deposits. Miner. Deposita 7: 202-216. https://doi.org/10.1007/BF00207155

[7] Dewaele, S., Goethals, H., Thys, T. (2013). Mineralogical characterization of cassiterite concentrates from quartz vein and pegmatite mineralization of the Karagwe-Ankole and Kibara belts, Central Africa. Geol. Belg., 16(1-2): 66-75.

[8] Melcher, F., Graupner, Torsten, Gäbler, Hans-Eike, Sitnikova,Maria, Henjes-Kunst, Thomas Oberthür, Gerdes, Axel, Dewaele, S. (2015). Tantalum-(niobiumtin) mineralization in African pegmatites and rare metal granites: Constraints from $\mathrm{Ta}-\mathrm{Nb}$ oxide mineralogy, geochemistry and U-Pb geochronology. Ore Geol. Rev., 64:

667-719. https://doi.org/10.1016/j.oregeorev.2013.09.003

[9] Pohl, W., Guenther, M.A. (1991). The origin of Kibarian (Late Mid-Proterozoic) tin, tangesten and gold quartz veins deposits in Central Africa: A fluid inclusion study. Min. Deposita, 26(1): 51-59. https://doi.org/10.1007/BF00202365

[10] Pohl, W. (1994). Metallogeny of northeastern Kibara belt, Central Africa-recent perspectives. Ore Geo. Rev., 9(2): 105-130. https://doi.org/10.1016/0169-1368(94)90024-8

[11] KokonyangI, J.W., Kampunzu, A.B, Armstrong., R., Yoshida, M., Okudaira, T., Arima, M., Ngulube, D.A. (2006). The Mesoproterozoic Kibaride belt (Katanga, D.R. Congo). Journal of African Earth Sciences, 46(1): 1-35. https://doi.org/10.1016/j.jafrearsci.2006.01.017

[12] Lehmann, B., Halder, S., Munana, J.R., Ngizimana, J.D.P., Biryabarema, M. (2014). The geochemical signature of rare-metal pegmatites in central Africa: Magmatic rocks in the Gatumba tin-tantalum mining district, Rwanda. J. Geochem. Explor., 144: 528-538. https://doi.org/10.1016/j.gexplo.2013.11.012

[13] Cailteux, J.L.H., Kampunzu, H.A.B. (2004). Third workshop of IGCP 450: Proterozoic sediment-hosted base metal deposits of western Gondwana, Lubumbashi, D. R.Congo. Episodes, 27(3): 209-213.

[14] Ndikumana, J.d.D., Bolarinwa, A.T., Adeyemi, G.O., Olajide-Kayode, J. (2020). Geochemistry of feldspar and muscovite from pegmatite of the Gatumba area, Karagwe Ankole Belt: implications for $\mathrm{Nb}-\mathrm{Ta}-\mathrm{Sn}$ mineralisation and associated alterations. SN Appl. Sci., 2(9): 1568. https://doi.org/10.1007/s42452-020-03370-1

[15] Theunissen, K. (1984). Les principaux traits de la tectonique Kibarienne au Burundi. UNESCO, Géol. for Economic Development. Newsletter, 2: 85-92.
[16] Klerkx, J., Liegeois, J.P., Lavreau, J., Claessens, W. (1987). Crustal evolution of the northern Kibaran Belt, Eastern and Central Africa. In Kröner, A.(ed.), Proterozoic lithospheric evolution. Geodynamics Series (American Geophysics Union), 17: 217-233.

[17] Goffart, G. (1933). Carte géologique du Kivu entre les méridiens $27^{\circ} 40^{\prime}$ latitude sud. ASGB, PRCB, t.,LVII, pp.c. $27-41$

[18] Villeneuve. (1980). Les formations précambriennes antérieures ou rattachées au Supergroupe de l'Itombwe au Kivu oriental est méridional (Zaïre). Bulletin de la Société belge de Géologie., 89(4): 301-308.

[19] Lavreau, J. (1985). Le groupe de la Ruzizi (Ruzizien du Zaïre, Rwanda et Burundi) à la lumière des connaissances actuelles. Mus. roy. Afr. centr., (Tervuren), Dép. Géol. Min., Rapp.ann., 1983-84, 111-119.

[20] Rumvegeri, B.T. (1987). Le Précambrien de l'Ouest du lac Kivu (Zaïre) et sa place dans l'évolution géodynamique de l'Afrique centrale et occidentale. Pétrologie et tectonique. Ph.D. Thesis, Université de Lubumbashi, Dépt. Géologie.314p., 1 carte.

[21] Laghmouch, M., Kalikone, C., Ilombe, G., Ganza, G., Delvaux, D., Safari, E., Bachinya, J., Dewaele, S., Wazi, N., Nzolang, C., Fernandez, M., Tack, L., Nimpagaritse, Kervyn, F., 2018. Production de la carte géologique du Kivu (1/500 000): méthodologie et résultats préliminaires Conférence sur la Géologie du Congo au CRGM, Kinshasa, RDC, 24-25/10/201.

[22] Fernanadez-Alonso, M., Cutten, H., De Waele, B., Tack, L., Tahon, A., Baudet, D., Barritt, S.D. (2012). The Mesoproterozoic Karagwe-Ankole Belt (formerly the NE Kibara belt): The result of the prolonged extensional intracratonic basin development punctuated by two short-lived far -field compressional events. Precambrian Res., 63-86.

[23] Dewaele, S., Hulsbosch, N., Cryns, Y., Boyce, A., Burgess, R., Muchez, P. (2015). Geological setting and timing of the world-class $\mathrm{Sn}, \mathrm{Nb}-\mathrm{Ta}$ and $\mathrm{Li}$ mineralization of Manono-Kitotolo (Katanga, Democratic Republic of Congo). Ore Geology Reviews 72

http://dx.doi.org/10.1016/j.oregeorev.2015.07.004

[24] Hulsbosch, N., Johanna, V.D., Nathan, R., Stijn, D., Dominique, J., Philippe, M. (2017). Structural control on the emplacement of contemporaneous $\mathrm{Sn}-\mathrm{Ta}-\mathrm{Nb}$ mineralized LCT pegmatites and Sn bearing quartz veins: Insights from the Musha and Ntunga deposits of the Karagwe-Ankole Belt, Rwanda. J. Afr. Earth Sci., 134: 24-32. https://doi.org/10.1016/j.jafrearsci.2017.06.004

[25] Moores, E.M., Twiss, R.J. (1995). Tectonics. Freeman and Company, New York, USA.

[26] Oyediran, I.A., Nzolang, C., Mupenge, M.P., Idakwo, S.O. (2020). Structural control and Sn-Ta-Nb mineralization potential of pegmatitic bodies in Numbi, South Kivu Eastern DR Congo. Lithos. 